\title{
Marek Zarębski
}

\section{KIERUNKI DZIAŁALNOŚCI MAŁYCH I ŚREDNICH PRZEDSIĘBIORSTW}

Z arys treści. W krajach o rozwiniętej gospodarce rynkowej udział sektora MSP w ogólnej liczbie podmiotów gospodarczych przekracza 90\%. Przedsiębiorstwa te zatrudniają 60-80\% ogólnej liczby zatrudnionych w gospodarce, a ich udział w tworzeniu dochodu narodowego wynosi od $60 \%$ do $90 \%$.

W latach 1996-2006 małe i średnie przedsiębiorstwa rozwinęły poziom i zakres wykonywanych usług. Zmniejszył się udział przedsiębiorstw handlowych i przemysłowych. W największym stopniu zmiany te dotyczą firm najmniejszych. Sytuacja sektora małych i średnich firm zróżnicowana jest nie tylko pod względem sektora własnościowego i rodzaju prowadzonej działalności. Znaczne różnice występują także w układzie regionalnym.

Słow a kluc zowe: małe i średnie przedsiębiorstwa, kierunki działalności.

\section{WPROWADZENIE}

Rozwój przedsiębiorczości w Polsce wiązał się z przyjęciem dwóch ustaw. Pierwsza z nich - ustawa o działalności gospodarczej z 1988 roku - zniosła prawne bariery wejścia na rynek oraz dała pełną wolność w podejmowaniu i prowadzeniu działalności gospodarczej bez formalnych wymogów kwalifikacyjnych ${ }^{1}$. Ponadto podmioty gospodarcze mogły zatrudniać dowolną liczbę pracowników bez pośrednictwa pracy. Miały także prawo dobrowolnego zrzeszania się w organizacje zawodowe.

1 Ustawa z dnia 23 grudnia 1988 r. o działalności gospodarczej (Dz.U. 1988, nr 41, poz. 324). 
Druga ustawa - o działalności gospodarczej z udziałem podmiotów zagranicznych z 1986 roku - dotyczyła stworzenia korzystniejszych warunków dla zagranicznych inwestycji w Polsce ${ }^{2}$. Istotnym czynnikiem było także zapoczątkowanie transformacji ustrojowej, czego przejawem było wprowadzenie ustawy o prywatyzacji przedsiębiorstw państwowych i o utworzeniu Urzędu Ministra Przekształceń Własnościowych ${ }^{3}$. Ustawa ta określała procedurę przekazywania majątku przedsiębiorstw państwowych w ręce prywatnych osób lub instytucji. Uregulowane $\mathrm{w}$ ustawie sposoby prywatyzacji wspomagały zachodzący w gospodarce proces tworzenia małych i średnich przedsiębiorstw opierających się na kapitale własnym przedsiębiorcy.

Istotne dla powstawania małej prywatnej przedsiębiorczości były także przemiany gospodarcze przejawiające się m.in. liberalizacją cen i handlu, ograniczeniem barier prawnych poprzez liberalizację zasad licencjonowania działalności gospodarczej oraz pojawieniem się nadwyżki popytu nad podażą po okresie niedoborów $w^{4}$.

\section{MAŁE I ŚREDNIE PRZEDSIĘBIORSTWA W GOSPODARCE RYNKOWEJ}

W krajach o rozwiniętej gospodarce rynkowej udział sektora MSP w ogólnej liczbie podmiotów gospodarczych przekracza $90 \%$. Przedsiębiorstwa te zatrudniają 60-80\% ogólnej liczby zatrudnionych w gospodarce, a ich udział w tworzeniu dochodu narodowego wynosi od $60 \%$ do $90 \%$.

Mała i średnia przedsiębiorczość w czasie trwania gospodarki centralnie planowanej miała pozycję marginalną. Jej tworzenie i prowadzenie było silnie ograniczane przez państwo. Silny rozwój przedsiębiorczości nastąpił dopiero po roku 1990, co wynikało przede wszystkim z następujących przyczyn ${ }^{5}$ : odblokowanie możliwości tworzenia firm prywatnych m.in. poprzez likwidację lub osłabienie instytucji kontroli firm prywatnych, wprowadzenie niskich ceł na wiele grup towarów, silne osłabienie sektora państwowego - zniesienie monopolu własności państwowej w obrocie towarów, likwidacja uprzywilejowanej pozycji postsocjalistycznych monopolistów, wprowadzenie podatku od ponadnormatywnych wynagrodzeń, obecność chłonnego rynku wewnętrznego oraz stosunkowo

2 Ustawa z dnia 23 kwietnia 1986 r. o spółkach z udziałem zagranicznym (Dz.U. 1986, nr 17, poz. 88 ).

3 Ustawa z dnia 13 lipca 1990 r. (Dz.U. 1990, nr 51, poz. 298).

4 Wysłocka (2004), s. 76.

5 Gardawski (2001), s. 21-25. 
słaba konkurencja na krajowym rynku, brak w pierwszym okresie transformacji konkurencji ze strony kapitału zagranicznego spowodowany postrzeganiem sytuacji w naszym kraju jako niestabilnej, obowiązujące przepisy niedostosowane do wymogów gospodarki rynkowej, a także otwarcie przed sektorem prywatnym rynku wschodniego - rynek ten szybko stał się rynkiem zbytu towarów przemysłu lekkiego i rolno-spożywczego. W rezultacie działania tych i innych czynników sektor małych i średnich przedsiębiorstw powstał stosunkowo gwałtownie, a wiele osób zdecydowało się podjąć ryzyko prowadzenia działalności gospodarczej na własny rachunek.

W okresie transformacji rozwój tego sektora spełniał szereg funkcji społecznych i gospodarczych. Podstawowe funkcje społeczne MSP to uformowanie klasy drobnych właścicieli, pochłanianie nadwyżek siły roboczej, kreowanie postaw przedsiębiorczych oraz wskazywanie możliwości samozatrudnienia, osiągnięcia sukcesu. Funkcje gospodarcze spełniane przez sektor MSP to m.in.:

- rozwój nowych dziedzin działalności gospodarczej poprzez tworzenie przedsiębiorstw produkujących nieznane dotąd produkty i dostarczających nowe usługi - MSP przyczynia się jednocześnie do pozytywnych zmian w strukturze gospodarczej;

- udział w formułowaniu prywatnej własności czynników produkcji (poprzez przejęcie i zagospodarowanie części wyposażenia prywatyzowanych przedsiębiorstw państwowych);

- wchłonięcie znacznych zasobów siły roboczej;

- wymuszenie zmian w prawie sprzyjających rozwojowi małej i średniej przedsiębiorczości.

Realizacja tych funkcji przyczyniła się do łagodzenia napięć społecznych i ograniczenia kosztów procesu transformacji.

W kolejnych latach funkcjonowania gospodarki rynkowej przyjmowane były programy rządowe określające szczególną politykę państwa wobec MSP. W 1995 roku przyjęty został program „Małe i średnie przedsiębiorstwa w gospodarce narodowej”. Dokument ten określał działania wspierane przez rząd, służące m.in.: ułatwieniu w powstawaniu i rozwoju MSP, zmniejszeniu ryzyka prowadzenia działalności gospodarczej, zwiększeniu konkurencyjności MSP, rozwojowi usług finansowych dla MSP. Kolejne programy rządowe to „Program rozwoju MSP w latach 1999-2002”, ,Rządowy program rozbudowy systemu funduszy pożyczkowych i doręczeniowych dla małych i średnich przedsiębiorstw w latach 2002-2006, Kapitał dla przedsiębiorczych” oraz „Kierunki

\footnotetext{
6 Markowski (2001), s. 38.

7 Misterstwo Gospodarki i Pracy, www.mgip.gov.pl (data dostępu: 20.11.2006 r.).
} 
działań Rządu wobec małych i średnich przedsiębiorstw od 2003 do 2006 roku"8. O znaczeniu tego sektora świadczy także poświęcenie mu odrębnego rozdziału w ustawie uchwalonej w 1999 roku: Prawo działalności gospodarczej ${ }^{9}$, a następnie w ustawie z 2004 roku o swobodzie działalności gospodarczej ${ }^{10}$.

Celem polityki państwa staje się pobudzenie aktywności gospodarczej sektora małych i średnich przedsiębiorstw, która zapewnia wzrost zatrudnienia w tym sektorze oraz wzrost jego konkurencyjności i zdolności do funkcjonowania na Jednolitym Rynku Europejskim, wspieranie przedsięwzięć służących rozwojowi małych i średnich przedsiębiorstw, poprawa otoczenia prawnego i administracyjnego małych i średnich przedsiębiorstw oraz rozwój postaw przedsiębiorczych w społeczeństwie, rozwój otoczenia instytucjonalnego małych i średnich przedsiębiorstw, wspieranie integracji firm w działalności na forum międzynarodowym.

Zainteresowanie państwa wspieraniem małej i średniej przedsiębiorczości jest tak znaczne, ponieważ rozwój tego sektora uznawany jest powszechnie za jedną z miar poziomu rozwoju gospodarczego kraju, a także objaw zdrowej konkurencji w gospodarce. Małe jednostki gospodarcze mają zdolność szybszego dostosowywania się do zmieniających się warunków rynkowych. Dzięki tej elastyczności łatwiej jest im przetrwać pojawiające się kryzysy. Małe i średnie przedsiębiorstwa rozwijają gospodarkę na poziomie lokalnym, korzystając z lokalnych surowców, zasobów siły roboczej, zaspokajając popyt na produkty i usługi najbliższych odbiorców. Ekspansja sektora MSP miała w Polsce szczególne znaczenie podczas okresu transformacji gospodarczej jako istotny czynnik wspierający tworzenie mechanizmów rynkowych. Obecnie dalszy rozwój tego sektora przyczynia się w znacznym stopniu do zbliżania struktury gospodarczej naszego kraju do gospodarek lepiej rozwiniętych.

\section{ROZWÓJ MSP W LATACH 1996-2002}

Po roku 1990 zmieniła się struktura rodzajów działalności prowadzonej przez małe i średnie przedsiębiorstwa. W tabeli 1. przedstawiono jak zmieniała się sytuacja w MSP aktywnych (bez rolnictwa) w latach 1996-2002. W 1966 roku najliczniejszą grupę stanowiły przedsiębiorstwa zajmujące się handlem i naprawami.

8 Tamże (data dostępu: 20.11.2006 r.)

9 Ustawa z dnia19 listopada 1999 r. o prawie działalności gospodarczej (Dz. U. 1999, nr 101, poz. 1178).

10 Ustawa z dnia 2 lipca 2004 r. o swobodzie działalności gospodarczej (Dz. U. 2004, nr 173, poz. 1807). 
Stanowiły ponad 40\% aktywnych MSP. Kolejną pod względem wielkości grupą były przedsiębiorstwa zaliczone do usług pozostałych poza wymienionymi w tabeli, a wśród nich najliczniejsze (około połowy) to jednostki prowadzące działalność w zakresie obsługi nieruchomości i firm. Następnie z 14\% udziałem plasowały się firmy przemysłowe, a na końcu z podobnym udziałem - około $10 \%$ - budownictwo oraz transport i łączność.

W latach 1996-2002 nastapił 6,5\% spadek liczby przedsiębiorstw zajmujących się handlem i naprawami. Mimo to nadal na koniec okresu grupa ta była najliczniejsza. Udział liczby przedsiębiorstw przemysłowych nieznacznie malał. W konsekwencji w 2002 roku był o ponad 2 punkty procentowe mniejszy niż w 1996 roku. Podobna tendencja wystapiła w przedsiębiorstwach transportowych. Najsilniejszy wzrost udziału odnotowano wśród firm z sektora usług pozostałych - o 9,5 punktu procentowego. W szczególności wzrost ten dotyczył podmiotów zajmujących się obsługą nieruchomości i firm (różnego rodzaju doradztwo: prawne, w zakresie księgowości, marketingu, reklamy, a także pośrednictwem przy sprzedaży nieruchomości $\left.{ }^{11}\right)$.

Tabela 1. Struktura rodzajów działalności aktywnych MSP w latach 1996-2002 (w \%)

\begin{tabular}{|l|c|r|r|r|r|r|r|}
\hline \multirow{2}{*}{ Gałęzie gospodarki } & \multicolumn{7}{|c|}{ Lata } \\
\cline { 2 - 8 } & 1996 & 1997 & 1998 & 1999 & 2000 & 2001 & 2002 \\
\hline Handel i naprawy & 42,4 & 40,0 & 39,4 & 38,5 & 37,0 & 37,0 & 36,0 \\
\hline Przemysł & 14,4 & 13,0 & 13,7 & 13,9 & 12,5 & 12,2 & 12,1 \\
\hline Budownictwo & 10,1 & 12,0 & 11,8 & 12,2 & 11,6 & 10,5 & 10,5 \\
\hline Transport i łączność & 10,0 & 10,0 & 10,3 & 9,7 & 9,0 & 8,4 & 8,8 \\
\hline Pozostałe usługi & 23,1 & 25,0 & 24,8 & 25,7 & 29,9 & 31,9 & 32,6 \\
\hline
\end{tabular}

Źródło: opracowanie własne na podstawie: M. Kubisza (red.), Raport o stanie sektora matych $i$ średnich przedsiębiorstw w Polsce w latach 1996-1997, Polska Fundacja Promocji i Rozwoju Małych i Średnich Przedsiębiorstw, Warszawa 1998, s. 86; W. Dzierżanowski (red.), Raport o stanie sektora matych i średnich przedsiębiorstw w Polsce w latach 1997-1998, Polska Fundacja Promocji i Rozwoju Małych i Średnich Przedsiębiorstw, Warszawa 1999, s. 27; idem (red.), Raport o stanie sektora matych i średnich przedsiębiorstw w Polsce w latach 1998-1999, Polska Fundacja Promocji i Rozwoju Małych i Średnich Przedsiębiorstw, Warszawa 2000, s. 28; idem (red.), Raport o stanie sektora matych i średnich przedsiębiorstw w Polsce w latach 1999-2000, Polska Agencja Rozwoju Przedsiębiorczości, Warszawa 2001, s. 35; idem (red.), Raport o stanie sektora matych i średnich przedsiębiorstw w Polsce w latach 2000-2001, Polska Agencja Rozwoju Przedsiębiorczości, Warszawa 2002, s. 26; A. Tokaj-Krzewska (red.), Raport o stanie sektora matych i średnich przedsiębiorstw w Polsce w latach 2001-2002, Polska Agencja Rozwoju Przedsiębiorczości, Warszawa 2003, s. 27; idem (red.), Raport o stanie sektora matych i średnich przedsiębiorstw w Polsce w latach 2002-2003, Polska Agencja Rozwoju Przedsiębiorczości, Warszawa 2004, s. 27.

11 Tokaj-Krzewska (red.) (2003), s. 28. 


\section{ROZWÓJ MSP W LATACH 2002-2006}

Dane dotyczące liczby przedsiębiorstw małych i średnich dostępne dla lat 2002-2006 są bardziej szczegółowe i obejmują wszystkie podmioty zarejestrowane w rejestrze REGON. Tabela 2. przedstawia liczbę i procentowe udziały firm danej sekcji gospodarki w wybranych latach. W rozpatrywanym okresie najliczniejszą grupę nadal stanowią podmioty z sekcji G - handel hurtowy i detaliczny, naprawa pojazdów i artykułów użytku osobistego. Obserwowany jest jednak

Tabela 2. Poziom i struktura MSP według rodzajów działalności w latach 2002-2006

\begin{tabular}{|c|c|c|c|c|c|c|c|}
\hline \multirow{2}{*}{$\begin{array}{c}\text { Sekcje } \\
\text { gospodarki }\end{array}$} & \multicolumn{2}{|l|}{2002} & \multicolumn{2}{|l|}{2004} & \multicolumn{2}{|l|}{2006} & \multirow{2}{*}{$\begin{array}{l}2002= \\
100,0\end{array}$} \\
\hline & $\begin{array}{c}\text { Liczba } \\
\text { przedsiębiorstw }\end{array}$ & $\begin{array}{c}\text { Struktura } \\
(\mathrm{w} \%)\end{array}$ & \begin{tabular}{|c|} 
Liczba \\
przedsiębiorstw
\end{tabular} & $\begin{array}{c}\text { Struktura } \\
(\mathrm{w} \%)\end{array}$ & $\begin{array}{c}\text { Liczba } \\
\text { przedsiębiorstw }\end{array}$ & \begin{tabular}{|c|}
$\begin{array}{c}\text { Struktura } \\
(\mathrm{w} \%)\end{array}$
\end{tabular} & \\
\hline Rolnictwo & 91645 & 2,65 & 83510 & 2,34 & 89631 & 2,47 & 97,8 \\
\hline Rybołówstwo & 1942 & 0,06 & 2124 & 0,06 & 1974 & 0,05 & 101,6 \\
\hline Górnictwo & 1913 & 0,06 & 2061 & 0,06 & 2237 & 0,06 & 116,9 \\
\hline $\begin{array}{l}\text { Przetwórstwo } \\
\text { przemysłowe }\end{array}$ & 375705 & 10,85 & 375805 & 10,52 & 373480 & 10,28 & 99,4 \\
\hline $\begin{array}{l}\text { Zaopatrzenie } \\
\text { w energię, gaz } \\
\text { i wodę }\end{array}$ & 3136 & 0,09 & 3390 & 0,09 & 3598 & 0,10 & 114,7 \\
\hline Budownictwo & 357287 & 10,32 & 355346 & 9,95 & 370318 & 10,19 & 103,6 \\
\hline Handel i naprawy & 1167725 & 33,72 & 1188817 & 33,28 & 1160556 & 31,93 & 99,4 \\
\hline $\begin{array}{l}\text { Hotele } \\
\text { i restauracje }\end{array}$ & 105849 & 3,06 & 113052 & 3,16 & 112703 & 3,10 & 106,5 \\
\hline $\begin{array}{l}\text { Transport, } \\
\text { składowanie, } \\
\text { łączność }\end{array}$ & 266850 & 7,71 & 262911 & 7,36 & 259190 & 7,13 & 97,1 \\
\hline $\begin{array}{l}\text { Pośrednictwo } \\
\text { finansowe }\end{array}$ & 123813 & 3,58 & 128935 & 3,61 & 129525 & 3,56 & 104,6 \\
\hline $\begin{array}{l}\text { Obsługa } \\
\text { nieruchomości } \\
\text { i firm }\end{array}$ & 513722 & 14,84 & 564914 & 15,82 & 602788 & 16,59 & 117,3 \\
\hline Edukacja & 71637 & 2,07 & 87856 & 2,46 & 93410 & 2,57 & 130,4 \\
\hline Ochrona zdrowia & 148098 & 4,28 & 150783 & 4,22 & 159693 & 4,39 & 107,8 \\
\hline $\begin{array}{l}\text { Pozostała } \\
\text { działalność } \\
\text { usługowa }\end{array}$ & 209664 & 6,05 & 227589 & 6,37 & 249253 & 6,86 & 118,9 \\
\hline
\end{tabular}

Źródło: opracowanie własne na podstawie: Główny Urząd Statystyczny, Zmiany strukturalne grup podmiotów gospodarki narodowej w 2006 r., Warszawa 2007, s. 30-45, Główny Urząd Statystyczny, Zmiany strukturalne grup podmiotów gospodarki narodowej w 2005 r., Warszawa 2006, s. 32-47, Główny Urząd Statystyczny, Zmiany strukturalne grup podmiotów gospodarki narodowej w 2003 r., Warszawa 2004, s. 30-45. 
dalszy, choć nieznaczny, spadek tego udziału. Kolejną dużą i szybko nieustannie rozwijającą się grupa jest sekcja $\mathrm{K}$ - obsługa nieruchomości i usługi związane z prowadzeniem działalności gospodarczej. Stanowiła ona w 2006 roku już ponad $16,5 \%$. Na względnie stałym poziomie około $10 \%$ utrzymują się podmioty zajmujące się budownictwem (sekcja F), a także przetwórstwem przemysłowym (D). Niewielki spadek udziału zanotowano wśród MSP należących do sekcji I transport, gospodarka magazynowa i łączność - w 2006 roku wynosił on ponad $7 \%$. W sumie wyszczególnione powyżej przedsiębiorstwa stanowią około $76 \%$ wszystkich MSP. Podmioty należące do pozostałych sekcji traktowane będą w dalszej analizie jako należące do jednej grupy. Są to m.in. firmy o działalności usługowej: hotele i restauracje, pośrednictwo finansowe, ochrona zdrowia, edukacja itd.

Wśród mikroprzedsiębiorstw (wykres 1) podobnie jak wśród wszystkich MSP najliczniejszą grupę stanowi sekcja G - handel i naprawy. Podobnie struktura pozostałych rodzajów działalności w latach 2002-2006 przedstawia się podobnie jak w całym sektorze MSP.

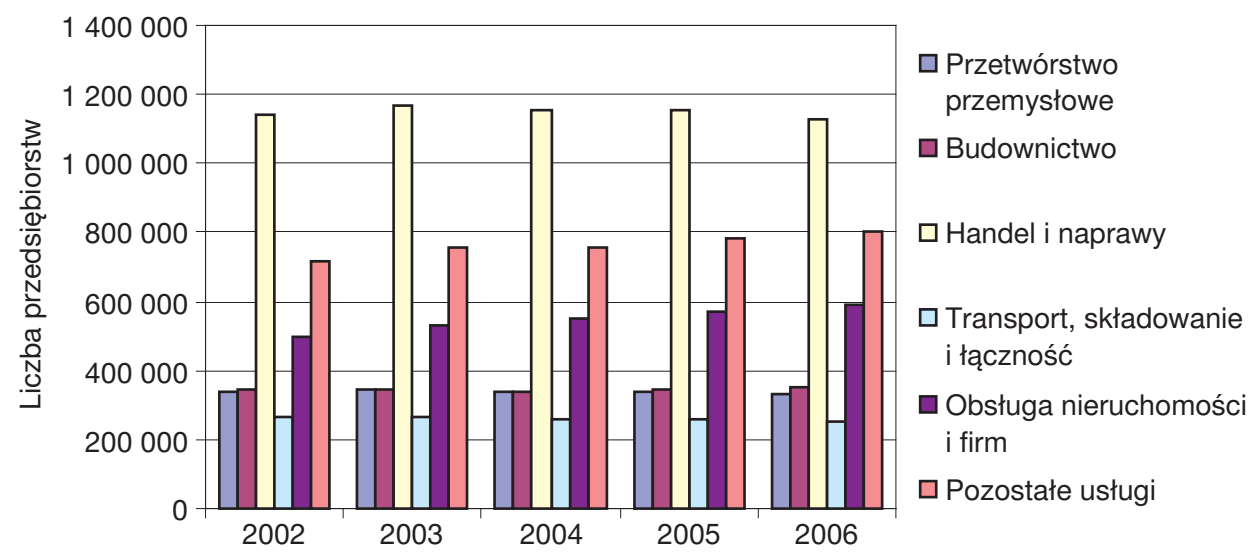

Wykres 1. Liczba mikroprzedsiębiorstw według sekcji gospodarki w latach 2002-2006 Źródło: opracowanie własne na podstawie: Główny Urząd Statystyczny, Zmiany strukturalne grup podmiotów gospodarki narodowej w 2006 r., Warszawa 2007, s. 30-45; Główny Urząd Statystyczny, Zmiany strukturalne grup podmiotów gospodarki narodowej w 2005 r., Warszawa 2006, s. 32-47; Główny Urząd Statystyczny, Zmiany strukturalne grup podmiotów gospodarki narodowej w 2004 r., Warszawa 2005, s. 28-43; Główny Urząd Statystyczny, Zmiany strukturalne grup podmiotów gospodarki narodowej w 2003 r., Warszawa 2004, s. 30-45.

Przedsiębiorstwa zatrudniające od 10 do 49 osób to najliczniejsza grupa w MSP. W strukturze tych przedsiębiorstw 40\% stanowiły firmy zajmujące się budownictwem, przetwórstwem przemysłowym, transportem i łącznością oraz 
obsługą nieruchomości. Następnie z udziałem około $20 \%$ plasuje się sekcja przetwórstwo przemysłowe nieznacznie przewyższając handel i naprawy. Około 11\% stanowią firmy budowlane, 7,5\% obsługa nieruchomości i firm, 3\% transport i łączność. Liczba małych firm należących do każdego rodzaju działalności spośród wyżej wymienionych, z wyjątkiem sekcji K (obsługa nieruchomości i firm) w rozpatrywanym okresie wzrastała. W przypadku działu gospodarki zajmującego się handlem i naprawami tendencja ta kształtowała się w przeciwnym kierunku niż w mikroprzedsiębiorstwach.

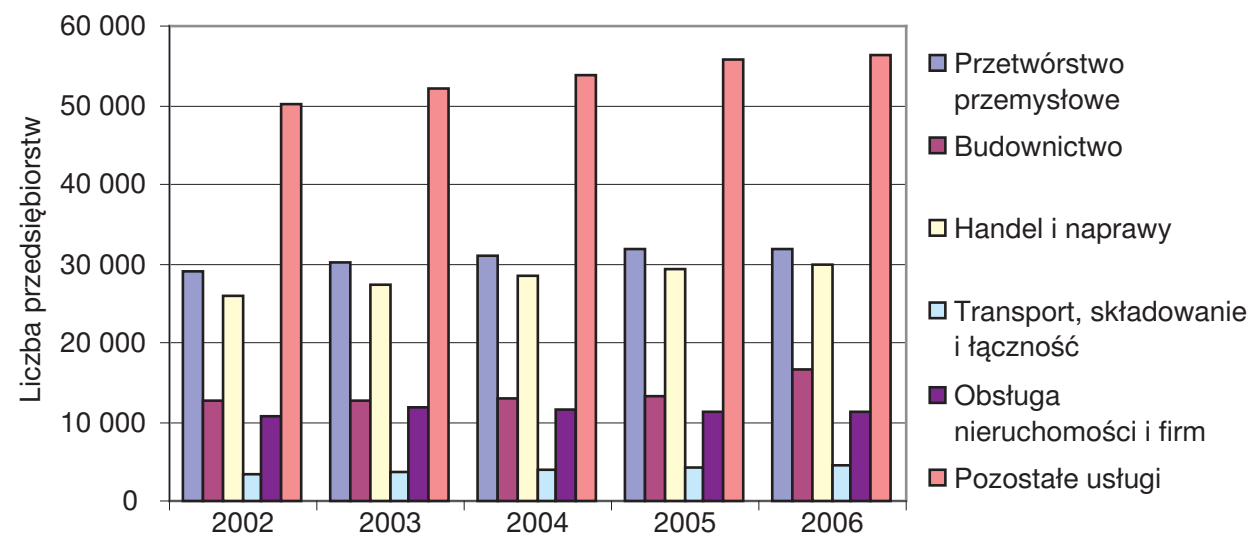

Wykres 2. Liczba małych przedsiębiorstw według sekcji gospodarki w latach 2002-2006

Źródło: opracowanie własne na podstawie: Główny Urząd Statystyczny, Zmiany strukturalne grup podmiotów gospodarki narodowej w 2006 r., Warszawa 2007, s. 30-45; Główny Urząd Statystyczny, Zmiany strukturalne grup podmiotów gospodarki narodowej w 2005 r., Warszawa 2006, s. 32-47; Główny Urząd Statystyczny, Zmiany strukturalne grup podmiotów gospodarki narodowej w 2004 r., Warszawa 2005, s. 28-43; Główny Urząd Statystyczny, Zmiany strukturalne grup podmiotów gospodarki narodowej w 2003 r., Warszawa 2004, s. 30-45.

Wśród firm średnich najwięcej, podobnie jak w przypadku małych, stanowią pozostałe sekcje - ponad $40 \%$ (są to między innymi przedsiębiorstwa zajmujące się wytwarzaniem i zaopatrywaniem w energię elektryczną, gaz i wodę, ochroną zdrowia itp.). Na drugim miejscu pod względem liczby firm znajduje się sekcja przetwórstwo przemysłowe - w 2006 roku udział wyniósł niecałe 30\% (wykres 3). Następnie z udziałami przybliżonymi do $10 \%$ plasują się handel i naprawy, obsługa nieruchomości i usługi związane z prowadzeniem działalności gospodarczej.

Liczba średnich firm przemysłowych w latach 2002-2006 wzrastała. Odwrotne zjawisko występowało w sekcji budownictwo oraz handel i naprawy. 


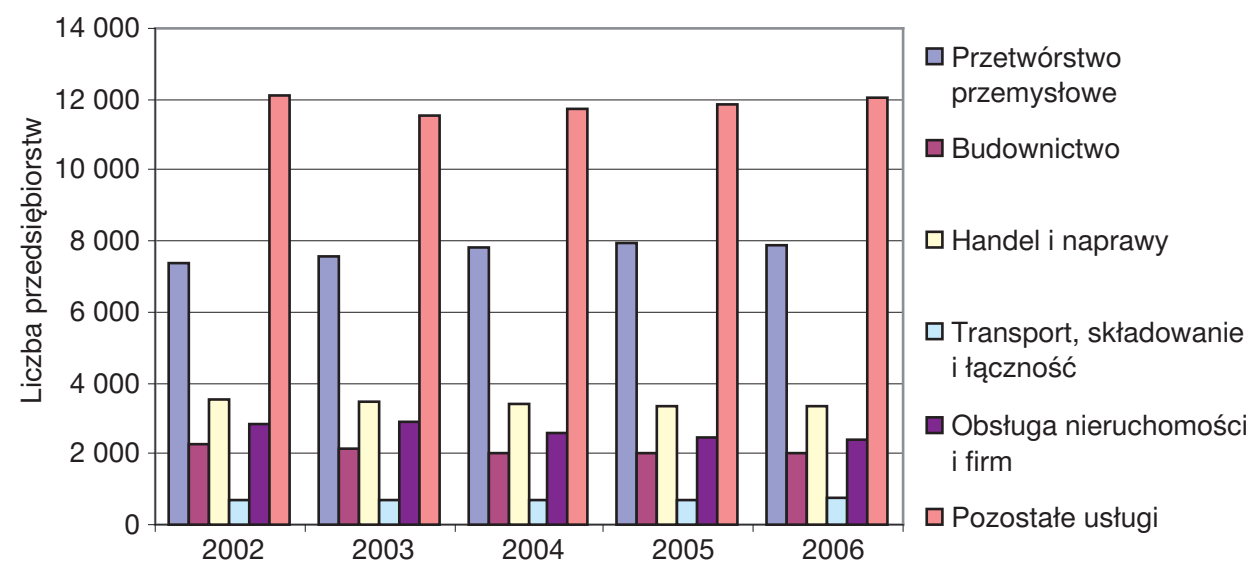

Wykres 3. Liczba średnich przedsiębiorstw według sekcji gospodarki w latach 2002-2006

Źródło: opracowanie własne na podstawie: Główny Urząd Statystyczny, Zmiany strukturalne grup podmiotów gospodarki narodowej w 2006 r., Warszawa 2007, s. 30-45; Główny Urząd Statystyczny, Zmiany strukturalne grup podmiotów gospodarki narodowej w 2005 r., Warszawa 2006, s. 32-47; Główny Urząd Statystyczny, Zmiany strukturalne grup podmiotów gospodarki narodowej w 2004 r., Warszawa 2005, s. 28-43; Główny Urząd Statystyczny, Zmiany strukturalne grup podmiotów gospodarki narodowej w 2003 r., Warszawa 2004, s. 30-45.

Liczebność sekcji K (obsługa nieruchomości i firm) w 2003 roku wzrosła do roku poprzedniego, a następnie w kolejnych latach corocznie spadała. Natomiast liczba pozostałych przedsiębiorstw początkowo zmniejszyła się, a od roku 2004 systematycznie wzrasta.

Zmiany zachodzące w rozwoju firm średnich i małych mają znacznie mniejszy wpływ na sytuację sektora MSP w porównaniu do zmian zachodzących w mikroprzedsiębiorstwach. Przyczyną takiej sytuacji jest znaczna przewaga liczby najmniejszych podmiotów nad małymi i średnimi. Właśnie dlatego struktura rodzajów działalności sektora małych i średnich przedsiębiorstw jest najbardziej zbliżona do struktury firm o liczbie pracujących do 9 osób.

W latach 1996-2006 znacznie rozwinęły się rodzaje działalności MSP związanych ze świadczeniem różnego rodzaju usług. Zmniejszył się natomiast udział przedsiębiorstw handlowych i przemysłowych. W największym stopniu zmiany te dotyczą firm najmniejszych. Sytuacja sektora małych i średnich firm zróżnicowana jest nie tylko pod względem sektora własnościowego i rodzaju prowadzonej działalności. Znaczne różnice występują także w układzie regionalnym. 


\section{PODSUMOWANIE}

W rozwiniętych krajach świata, jak i w Polsce MŚP stanowią siłę napędową gospodarek. Wspieranie ich rozwoju, w tym zwłaszcza działalności innowacyjnej, jest zatem warunkiem koniecznym pozytywnych zmian w gospodarce. Przemiany, które w obrębie tego segmentu zachodzą w Polsce, wyraźnie wskazują, iż umacniają one swoją pozycję, zwłaszcza w obrębie działalności usługowej. Ich sytuacja pozostaje zróżnicowana w przekroju branż, wielkości mierzonej poziomem zatrudnienia, segmentów działalności, regionów.

\section{LITERATURA}

GUS (2000-2007), Roczniki statystyczne dla lat 2000-2007, Warszawa.

Gardawski J. (2001), Powracajaca klasa: sektor prywatny w III Rzeczpospolitej, Wydawnictwo Instytutu Filozofii i Socjologii Polskiej Akademii Nauk, Warszawa.

Markowski W. (2001), Abc small business'u, Wydawnictwo Marcus, Łódź.

Ministerstwo Gospodarki i Pracy, www.mgip.gov.pl (data dostępu: 20.11.2006 r.).

Tokaj-Krzewska A. (red.) (2003), Raport o stanie sektora małych i średnich przedsiębiorstw w Polsce w latach 2001-2002, Polska Agencja Rozwoju Przedsiębiorczości, Warszawa.

Wysłocka E. (2004), Małe i średnie przedsiębiorstwa w Unii Europejskiej, [w:] Determinanty rozwoju matych $i$ średnich przedsiębiorstw, pod red. J. Adamczyka, P. Bartkowiaka, Wydawnictwo Naukowo-Techniczne, Warszawa.

Ustawa z dnia 23 grudnia 1988 r. o działalności gospodarczej, Dz.U., 1988, nr 41, poz. 324 .

Ustawa z dnia 23 kwietnia 1986 r. o spółkach z udziałem zagranicznym, Dz.U., 1986, nr 17, poz. 88 .

Ustawa z dnia 13 lipca 1990 r., Dz.U. 1990, nr 51, poz. 298.

Ustawa z dnia 19 listopada 1999 r. prawo działalności gospodarczej, Dz.U. 1999, nr 101, poz. 1178.

Ustawa z dnia 2 lipca 2004 r. o swobodzie działalności gospodarczej, Dz.U. 2004, nr 173, poz. 1807. 


\section{DIRECTIONS OF ACTIVITIES FOR SMALL AND MEDIUM FIRMS}

A b stract. In countries with developed economy, the participation of small and medium firms in the whole number of economic subjects exceeds $90 \%$. These enterprises employ $60-80 \%$ out of the total number of workers in economy, and their participation in creating GNP is of $60 \%-90 \%$.

In the years 1996-2006 small and medium firms developed their level of productivity as well as the range of services. The participation of business and industrial companies got decreased. Most changes concern the smallest companies. The situation of small and medium firms is diversified not only because of the scale of property and the kind of activity but also considerable differences appear within the system of regions.

K e y w ord s : small and medium firms, directions of activities. 
